\title{
James F. Wilson, Legalistic Free-Soiler
}

\author{
By EARLE D. Ross
}

\section{A Neglected Biography}

Of the many distinguished Iowans whose careers have had no adequate biographical interpretation, in view of his influence upon state and national policies, perhaps the most signally neglected has been James Falconer Wilson (1828-1895). In an obituary appreciation in 1895 Charles Aldrich gave confident prediction that so achieving a leader would attract a competent and understanding biographer. ${ }^{1}$ But somehow, after nearly three score years not even the stimulus of a doctoral dissertation has induced such a study.

Certainly the investigation should be highly rewarding. In a turbulent period the career was one of unusual unity of purpose and consistency of policy. Hence, the professional and political activities are significant not only in themselves but in symbolizing a certain type of mind and method of leadership.

Formative Years

Like many eminent public men of the middle period Wilson's rise from humble origins was a real life story more remarkable than an Algerian romance. Born at Newark, Ohio, of a poor but highly respected family, at ten he became the main dependence of his widowed mother. As an apprentice he learned the trade of harness maker which he followed for a few years. Meanwhile largely by self instruction he had acquired a good basic education. On this foundation he began in

1 Certain sources of information were available at that time-such as the unrecorded observations of associates and Wilson's personal papers-which no longer exist. Scattered manuscript materials may be found in the papers of Allison, Grenville Dodge, Kirkwood, Kasson and others.

Printed sources for his career include Debates Const. Con. of Iowa (1857); Journal House of Rep. 7th Gen. Assem. of Iowa, (1858); Journal of Senate 8th Gen. Assem. of Iowa (1860); same extra session (1861); Cong. Globe, 57-60 Cong. (1861-1869); Con. Record, 48-53 
his spare time the reading of law which he completed with a brilliant young attorney, William B. Woods who was destined to reach the supreme court of the United States. For a young man with good reasoning powers and habits of concentrated application such a rigorous method was admirable.

Following his admission to the bar and marriage, like a host of ambitious young professional men of the Old Northwest, he sought the more immediate opportunities of the developing Middle Border. In 1853, the young couple came to Fairfield, Iowa, which was to be their future home.

\section{Pioneer Free-SoILer}

It was a strategic time for a young man of his talents and convictions. Free soil sentiment in the state was steadily mounting and the election of Grimes the following year put Iowa definitely in the line of the new departure. The young attorney gave tireless support to the new party movement in speeches, editorials in the local paper, and leadership in organizations. He was a delegate to the organizing convention of the Republican party in Iowa on February 22, 1860, and later was chosen one of the five delegates at large to the historic Chicago convention.

From the scanty records of the individual preferences of the Iowa delegation, it is known that Wilson stood firmly against a compromise on candidates or

Cong. (1883-1895); Trial of Andrew Johnson (1868); House Rep. No. 77, 42 Cong. 3 Sess. ("Credit Mobilizer") (1873); House Rep. ("Union Pacific Affairs") (1873); "James F. Wilson" (a symposium by C. M. Junkin, W. B. Allison, E. H. Conger, S. H. M. Byers), Midland Monthly, IV, 48-55 (1895); James F. Wilson, "Thought in Education," Annals of Iowa (2nd Ser.) I, 85-98; (1882); "The Bible and Science," ibid., 105-116 (1882); "Christian W. Slagle," Iowa Hist. Record, III, 529-543 (1887); William H. Barnes, Hist. of the ThirtyNinth Cong. of the U. S. (1867); Edward McPherson, Political Hist. of the U. S. A. During the Great Rebellion (1882); same, Pol. Hist. of the U. S. During the Per. of Reconstruction (1880); Fairfield Ledger, Apr. 24, May 1, 8, 1895; Iowa State Register, April 23, 24, 1895. Secondary writings of value include C. J. Fulton, Hist. of Jefferson County, Iowa (1914); D. E. Clark, Hist. of Senatorial Elections in Iowa (1912); E. P. Overholtzer, Hist. of U. S. Since Civil War (5 v. 191737).

Biographies and memoirs of leading contemporaries contain scattered references. 
platform. Backed by a home town that had early formed an "Irrepressible Club" and that organized the first band of "Wide Awakes" in the state, he contributed in full measure to the impressive majority for Lincoln which forecasted the future trend of the "Vermont of the West."

\section{State Legislator}

Meanwhile state offices had fairly been thrust upon him. In 1857, as a member of the state constitutional convention, he was appointed to eight committees and made chairman of that on state debts.

Wilson's thorough grounding in basic legal principles found early recognition in a new state where broad and exact legal knowledge was at a premium. In spite of youth he was not backward in expressing opinions on a variety of important matters, as is evidenced by the five and a half columns of index under his name. The same year Governor Grimes appointed him a commissioner of the highly controversial Des Moines River Improvement project.

Finally to top off a more than full year, he was elected representative to the Seventh General Assembly, which was the first to convene at the new capital in January, 1858. Incredible for a freshman member, he was made chairman of ways and means, as well as securing membership on two other major committees, banks and incorporations.

The next year his district promoted him to the senate. In the regular session he participated in code revision and in the special session, in the absence of the lieutenant governor, he served as president pro tem with general approval. It is evident that the serious, self-educated young lawyer was regarded by his associates as "young in years but in sage counsel old." There is no evidence that he felt any doubt as to his ability to assume responsibilities as they came to him so naturally.

Becomes AN M. C.

From such thorough and rapid proving in the state 
realm he was called to the national sphere in the most critical years that the Union had experienced.

In the summer of 1861, Gen. Samuel R. Curtis, one of the two Iowa representatives, resigned to enter the army and Wilson was elected to the vacancy. He was reelected for three successive terms and thus served during the crucial 37th-40th congresses (December 1861-March 1869).

During his first term the absence of the other representative, Col. William Vandever with his regiment, gave the new member the duties and responsibilities of looking after the interests of the entire state. At the same time, the situation gave him unusual influence and standing for a new member.

One important early service that he was enabled to render was in furthering the appointment of a distinguished Iowan, Samuel F. Miller, to the supreme court. In putting through a measure to readjust federal circuits and in securing the endorsements of a large proportion of representatives his aid was regarded as determining.

With the Thirty-eighth congress, in 1863, the Iowa representation was increased to six. It was a strong delegation, including such notables as Allison, Grinnell, and Kasson. But the member from the first district was by no means overshadowed by such distinguished associates.

\section{CIVIL War Legislator}

In Washington, as back in Iowa, his legal skill found immediate recognition. In his first term he was appointed to the judiciary committee and at the beginning of the second term he was elected to the chairmanship, which he continued to hold throughout his service. This committee had a key influence in framing war and reconstruction legislation, and Wilson was thus enabled to serve the free-soil cause more effectively than he could as a member of the select committees on the conduct of the war and of reconstruction.

In fact his legislative record charts the evolving war 
program. Early in his service he presented a resolution to add to the articles of war a prohibition of the use of the armed forces to return fugitive slaves. He served on the select committee on compensated emancipation for the border states. In January 1863, he introduced a joint resolution "to approve, ratify, and confirm" the Emancipation Proclamation. The interests of the soldier and sailor were regarded in the initiation of an amendment to the homestead act to commute the residence period by that of military service.

Finally and mainly, singly or jointly, resolutions were formulated and presented which embodied the essential principles of the war amendments. In particular he led the support in the house of the Civil Rights bill of 1866, the forerunner of the 14th amendment, against charges of unconstitutionality in a speech, which, in the judgment of Blaine, "was of great strength and legal research."

At the same time the business lawyer was by no means indifferent to the far-reaching departures that war economy was taking. He sought to moderate the income tax in the lower brackets. To secure more fully the new credit system, he proposed the tax on state bank issues. While favorable to what he regarded as reasonable protection, he opposed in the interests of his region the inordinate increases proposed in 1866. He gave hearty support to the homestead act and the railroad grants, but, like certain other prominent midwesterners in both houses, he opposed the Morrill college land-grant act as unfavorable to the landed states.

\section{Reconstruction Leader}

In the conflict between presidential and congressional authority in reconstruction, by constitutional conviction and partisan devotion to the great cause, Wilson had an intransigent commitment to the full and final jurisdiction of congress. As an old-line Whig he naturally emphasized legislative supremacy and his public service had all been with that branch. A decade before in the state constitutional convention he had 
asserted that he was "no friend to the veto power." The issue had appeared only at an incipient stage under Lincoln. Wilson was loyal throughout to the freesoil president; he was a member of the delegation to notify Lincoln of his second nomination and was given at his request the original manuscript of the acceptance address. (Now on file at Iowa State Department of History \& Archives.)

None the less, from the closing months of the war, Wilson as chairman of the judiciary committee, had asserted by declamatory resolutions the determining power of congress over restoration of the seceded states. In such formulations of policy he generally found himself in agreement with the aims and methods of the radical members of the committee on reconstruction. In effect he served as counselor for the "thorough" congressional reconstructionists in finding at every turn a legal course of action. In his judgment military reconstruction was essential both for justice and expediency, and he frankly asserted that the only permanent security for the cause was in maintaining Republican supremacy in the South on the basis of the remnant of loyal whites and the freedmen.

To realize these ends he would maintain legislative supremacy over judicial as well as executive authority. He thus subtly and adroitly prevented a judicial review of military reconstruction by adding to a general judicial act an amendment repealing the jurisdiction of the supreme court under the habeas corpus act of 1867.

At the same time, he drew the line at irregular, nonjudicable tactics. With all his zeal for the complete free-soil program, what he would, he would legally -according to the code and the regular procedure. On this stand he broke sharply with the irresponsible extremists over the preliminary, fantastically concocted charges of impeachment.

These emotional diatribes and imaginary assumptions presented under guise of a bill of high crimes Wilson regarded both as a travesty on the rules of evi- 
dence and an affront to the dignity of his committee. He carried a minority report to the floor of the House where after an argument "able and positive, holding the attention of members in a marked and exceptional degree" the spurious charges were overwhelmingly rejected. Could both sides have kept at least to the letter of the law the scandalous perversions of the impeachment trial might have been avoided. But seemingly passions and ambitions had been aroused to the degree where no holds were barred.

\section{MANAGER OF IMPEACHMENT TRIAL}

With the open violation of the tenure-of-office act, which he had helped to draft, Wilson felt that the struggle had changed completely; a definite case had arisen. In his view a "high crime" had been committed for which the constitutional safeguard should be invoked. Whatever the ultimate decision of the court as to the constitutionality of the act (a test that the radicals were careful to prevent) so long as the statute was in force, he argued, it was to be obeyed without question. Fessenden's contemporary opinion that Wilson had departed from "his usual discretion" and Cyrenus Cole's later charge that he had "succumbed to popular clamor" fail to take account of the real if nice distinction which he made between intent and attitude and the resort to an overt act.

Whatever the motive, Wilson's support to their crowning effort brought great elation to the radical camp. His selection as a member of the committee to formulate the articles of impeachment and as one of the trial managers was a recognition of his legal standing and his influence with the more moderate element of the party. To a pettifogger like Butler and to fanatics like Stevens and Boutwell he was undoubtedly valued mainly as respectable window dressing-something of which their case was in great need.

In the trial the leading lawyer of the prosecution who was the only equal of the distinguished talent retained by the defense, was given little opportunity to demonstrate his learning and reasoning powers. His main 
contribution was an argument on the responsibility of the executive to observe an act of congress regardless of his opinion and that of his advisers as to its constitutionality. On this point he presented an elaborate disquisition based upon long and rigorous preparation. Such a learned presentation kept the solemn tribunal from being quite the kangaroo court that the blatant managers deliberately sought to make it. Whatever the outcome, the legalist's standard of argument and method of procedure would have prevented what a leading authority in American constitutional history has termed "the most regrettable and shameful exhibition of personal spite and ruthless partisanship in American history."

\section{A RaIrRoad INTERLude}

Following his service in this stormiest of congresses, Wilson voluntarily retired to private life and the practice of his profession. Had he desired to remain in the public service the highest appointive positions could have been his for the taking. Certainly this was assured so far as the incoming president was concerned.

General Grant was so impressed by the soundness of Wilson's advice during the controversy over the control of the war department that he was quoted as saying "... James F. Wilson of Iowa ... is the clearestheaded man in congress." He gave signal demonstration of this respect by offering the retiring representative the headship of the department of state. Unfortunately Grant soon countered this selection by the maladroit temporary appointment of a close friend, Elihu Washburn, with the understanding that neither appointments or policies would be initiated by him. When the conditions were broken, Wilson refused to serve. He declined two later offers to enter Grant's cabinet and, according to well-founded reports, that of Garfield.

Wilson was not one to "hunker" for office, especially in executive service. What he wrote of his fellow townsman, Christian Slagle, that "he seemed not inclined to enter upon the strife" which so often attended 
getting and holding office, undoubtedly expressed his own personal feeling.

During the next decade and a half he devoted himself largely to his profession, the improvement of his suburban farm, and to community projects. The only public position which he held in these years was that of a director of the Union Pacific railroad company for six years under Grant and one under Hayes.

His connection with this railroad, in and out of congress, brought Wilson's name into two of the investigations so numerous and notorious in this periodthose dealing with the credit mobilier and the general management of the road. Unlike many prominent national figures, who sought to equivocate or prevaricate regarding the transaction, Wilson admitted frankly that he had invested $\$ 1,000$ (a fifth of what he had sought) in the stock of the construction organization, but when he had come to doubt the soundness of the management he disposed of his holdings. To the charge that he had been paid a substantial retainer from a special "expense fund," he made an emphatic denial and no substantiating proof was presented. While his admission and defense brought unfavorable comments from certain eastern journals, there is no evidence that the connection weakened his standing in the state. Probably the great majority of his fellow citizens agreed with his view that his contribution to and relations with this great regional and national enterprise had been not only legally above board but far-sighted and public spirited.

\section{In The U. S. Senate}

From 1866, Wilson had been mentioned for the senatorship and he was the chief rival of Allison in 1872. But he did not press his candidacy or engage in the bitter party struggles of the following decade, and consequently made no enemies. Hence in 1882, with the withdrawal of lesser candidates, the office came to him naturally and without the personal bitterness that had attended most of the previous legislative selections. Samuel S. Storrs commented editorially in the ANNaLs 
of IowA, "It is amusing to see Mr. Wilson ride triumphantly into the United States senate. One candidate after another dropped out of the list, till Wilson stood alone in solitary grandeur." His reelection was as readily secured.

In the senate he could not have the relative influence that he had exerted in the house. His service on committees was conscientious and competent. He was especially active in the regulation of interstate commerce and was influential in the drafting and enactment of the original act of 1887 .

Next to his great cause of anti-salvery was that of prohibition, and to this reform he gave a large portion of his waning physical strength and persuasive effort. Personally he was a strict teetotaler and an original member of the Sons of Temperance.

He was outspoken in the faction that sought to commit the Republican party to this reform, which in 1883 he urged upon the state convention. The proposal gained sufficient support to be a leading issue in the state election six years later.

Now in congress, he secured the enactment of the "original package" act which was regarded at the time as a notable safeguard for the dry states.

For years his health had been rapidly declining and he barely survived the end of his term. He failed to reach quite the biblical span, but his years had been full and useful to an unusual degree.

\section{A Summing UP}

James F. Wilson's career fell in an era of distressingly low standards in public service and private business, resulting from the strains and stresses of internal strife and the unsettlement and disorganization of epochal economic and social transition. He was inevitably a man of his time, subject to its attitudes, prejudices and errancies. But he was one of its better representatives, who rose well above the average of its political and professional leaders. If at times in his zeal for the great cause and the party which he identified with it, he resorted to legal and legislative 
finesse-took all the tricks that the law allowed-in sharp contrast to the fanatic, the demagogue, and the spoilsman, he was careful to keep within the bounds of the code and of the regular rules of procedure.

In training and personal conviction this son of the Old Northwest had a deep puritanical sense of personal and public probity and of his obligations to the general interest, in all relationships. He was a strictly orthodox churchman of the "old school." In background and temperament he was a crusader, especially for his major causes, which he promoted relentlessly regardless of personal interest. Rhetorically, but with essential truth, Johnson Brigham recorded that "His life-blood went into the anti-slavery movement and the long struggle for the enfranchisement, and into the movement for the restriction of the sale of intoxicating liquors." But most enduring of all, despite all the pressures and provocations of a stressful career, he was a consistent champion of that most basic safeguard of responsible government and of individual security, in peace and war, prosperity and depression, government under law.

\section{History Preserved at Its Source}

The first national historical society was founded in the midst of the Second War of Independence, Oct. 24, 1812, by Isaiah Thomas, one of the great pioneer editors of the nation. He was the founder of the Massachusetts Spy, which had an important part in the formulation of public opinion in favor of the original war of independence. He moved it to Worcester in 1775 , to escape seizure of his plant by the British, and kept it there after the Revolution.

Consequently, Worcester became the home of the American Antiquarian Society, which Thomas organized and endowed. He was a far-seeing man who bequeathed a fortune to be devoted to preserving the annals and relics of patriotism and progress for the benefit of succeeding generations. He thus established a new pattern of philanthropy. 
Copyright of Annals of Iowa is the property of State of Iowa, by \& through the State Historical Society of Iowa and its content may not be copied or emailed to multiple sites or posted to a listserv without the copyright holder's express written permission. However, users may print, download, or email articles for individual use. 